\title{
Preparation of Sour Grape (Vitis Vinifera) Beverages and Evaluation of their Storage Stability
}

\author{
Karakala Balaswamy, Pamidighantam Prabhakara Rao, Allani Nagender and Akula Satyanarayana*
}

Central Food Technological Research Institute (Council of Scientific and Industrial Research), Resource Centre, Habshiguda, Uppal Road, Hyderabad-500 007, India

\begin{abstract}
'Thompson seedless' grapes (Vitis vinifera) possessing $<13^{\circ}$ brix and $>1.0 \%$ acidity were used in the preparation of beverages with and without carbonation. Sour grape juice was extracted, bottled and clarified by racking for three months. Palatable blended grape beverages were also prepared using sour grape juice with phalsa / purple grape juice. Process parameters such as quantity of juice, blending proportions and brix / acid ratio for different beverages were optimized. Squashes were prepared by maintaining brix at $45^{\circ}$ and acidity $0.75 \%$. Readyto-serve (RTS) beverages were standardized with brix $15^{\circ}$ and acidity $0.14 \%$. The appearance, color and flavor characteristics of sour grape beverages were improved by blending with purple grape juice and phalsa juice at $2: 1$ and 1:1 ratios respectively. A set of carbonated beverages in the above combinations were also prepared to check their compatibility and acceptability. A marginal rise in total sugars and decrease in acidity were observed in all beverages after 6 months of storage. Sensory evaluation indicated that carbonated beverages were highly acceptable than plain beverages throughout the storage period. Highest scores of 7.4 and 7.5 were recorded for blended grape beverages with purple grape and phalsa juice respectively even after a storage period of 6 months.
\end{abstract}

Keywords: Sour grapes; Phalsa; Purple grapes; Blended beverages; Carbonated beverages

\section{Introduction}

Fruit beverages are well relished by all age groups of the society. Sour grapes (Vitis vinifera) 'Thompson seedless' are grown in some parts of Punjab, Haryana, and Tamil Nadu possess low total soluble solids $\left(<13^{\circ}\right.$ brix) with higher titratable acidity $(>1 \%)$ which are not suitable for consumption as table variety. Recently, sour grapes were explored in our laboratory for the production of various shelf stable products such as raisins, jam, spread, sweet chutney and canned grapes [1]. It was reported that consumption of grape products at moderate level helps in prevention of aging related diseases [2]. Since higher acidity is a major obstacle in fruits for consumption, fruit juices were subjected to de-acidification by electro dialysis [3], and palatable raisins were produced from sour grapes by osmo-air dehydration [4]. Literature review revealed various combinations of fruit juice, sugar and citric acid in preparation of ready - to - serve (RTS) beverages such as mango-papaya nectar, guava-lemon and papaya-passion fruit juice blends etc [5-7].

Blending of fruit juices is practiced to overcome the high cost of some exotic fruit juices, scarcity or seasonal availability, balancing of strong flavors, high acidity, astringency, or bitterness, improving total soluble solids, bland flavor, improving and stabilizing color. Nutritional or phytochemical properties can be improved by blending which offers to adjust sugar/acid ratios and compensate undesirable juice consistency [8].

Comminuted guava drinks were prepared maintaining the ratio of fruit bases to water at 100:200 and sugar to acid ratio at 450:7.6 to obtain superior organoleptic properties [9]. Guava beverages were prepared using $5,10 \%$ peeled fruit pulp, with $12.5 \%$ total soluble solids and $0.25 \%$ acidity. The beverages were preserved using $70 \mathrm{ppm} \mathrm{SO}_{2}$, $120 \mathrm{ppm}$ sodium benzoate, and pasteurization at $85^{\circ} \mathrm{C}$ for $15 \mathrm{~min}$ [10]. The juices were also assessed for retention of vitamin $\mathrm{C}$ and flavor in presence of carbonated water. The effect of potassium metabisulfite (100 ppm) was studied in non-pasteurized muscadine grape juice during storage at $3^{\circ} \mathrm{C}$ for 9 weeks. It was observed that sulfitation lightened the red color and lowered microbial levels [11]. Processes for extraction of lime juice and preparation of carbonated beverages were well documented in the literature [12]. Preservation of a carbonated lime drink in glass bottles prepared using a base in sugar syrup diluted with chilled carbonated water was described [13]. Blended muscadine grape beverages were prepared using $25 \%$ juice and addition of other juice namely, commercial grape juice, orange juice, and pineapple juice maintaining a brix/acid ratio of 30 [14]. Higher overall acceptability and enhanced vitamin $\mathrm{C}$ content was achieved by blending gooseberry juice with grape juice at 20:80 ratios [15]. Antioxidant capacity of soybased beverages was enhanced by blending with strawberry or grape fruit juices [16]. A method of preparation of carbonated RTS beverages using pomegranate syrup was described [17]. The pomegranate syrup consisted of $100 \%$ fruit juice, $0.5 \%$ citric acid and brix was maintained at $65 \%$. The syrup was diluted to 5 times and then carbonated. Carbonated RTS beverage from acidic tamarind pulp was developed by exposing the pulp to mixture of food enzymes [18]. Tamarind RTS beverage was prepared using $12.5 \%$ tamarind extract, $0.4 \%$ acidity and adjusting to $16^{\circ}$ brix. It was demonstrated that carbonated coconut beverages packed in glass bottles with crown cork seal can be safely preserved for 6 months period at an ambient temperature range of 28 $32^{\circ} \mathrm{C}[19]$.

In the present study, products such as squash and ready to serve (RTS) beverages were prepared from grapes possessing low total soluble solids and high acidity which are hitherto not reported. Blended grape

*Corresponding author: Akula Satyanarayana, Central Food Technological Research Institute (Council of Scientific and Industrial Research), Resource Centre Habshiguda, Uppal Road, Hyderabad-500 007, India, E-mail: rchyderabad@cftri. res.in

Received April 23, 2011; Accepted June 10, 2011; Published July 12, 2011

Citation: Balaswamy K, Rao PP, Nagender A, Satyanarayana A (2011) Preparation of Sour Grape (Vitis Vinifera) Beverages and Evaluation of their Storage Stability. J Food Process Technol 2:116. doi:10.4172/2157-7110.1000116

Copyright: (C) 2011 Balaswamy K, et al. This is an open-access article distributed under the terms of the Creative Commons Attribution License, which permits unrestricted use, distribution, and reproduction in any medium, provided the original author and source are credited. 
RTS beverages were prepared with purple grape and phalsa juices to improve the organoleptic attributes. Carbonated RTS beverages were also prepared for comparison with non-carbonated RTS beverages during storage.

\section{Materials and Methods}

'Thompson seedless' sour grapes with less than $13^{\circ}$ brix and acidity more than $1.0 \%$ were procured directly from grape orchards, Theni, Tamil Nadu, India. Purple grapes were purchased from the local fruit market, Hyderabad. Fully ripe and fresh phalsa (Grewia asiatica L.) fruits were procured from orchards situated at Acharya N.G. Ranga Agricultural University, Hyderabad. Carbonated water (Bisleri, Mumbai, India) was procured from a local market for use in preparing carbonated RTS beverages. Chemicals of laboratory grade were procured from S.d. fine Chemicals, Mumbai, India. Glass bottles of 200 and $750 \mathrm{ml}$ capacities were collected from M/s Associated Glass Works, Hyderabad.

Grape bunches were cleaned in running water and the berries were manually separated. Grape juice was extracted in a motorized juice extractor (Jassica, Mumbai, India). The juice was strained through muslin cloth and bottled in $750 \mathrm{ml}$ pre-sterilized glass bottles along with $1000 \mathrm{ppm} \mathrm{SO}_{2}$, crown corked and kept for racking for 3 months. Similarly juice from purple grapes was extracted, bottled by heat sterilization and kept for racking. The clarified grape juices were carefully decanted and used for the preparation of beverages. Clear phalsa fruit juice was extracted using basket press and used for blending with grape juice. The extracted and racked juices and beverages were analyzed for ${ }^{\circ}$ brix, acidity, $\mathrm{pH}$, reducing sugars and total sugars as per standard methods [20].

\section{Preparation of squash and ready-to-serve (RTS) beverages}

Squash and RTS beverages were prepared by following standard procedures. Grape squashes were prepared with $45^{\circ}$ and $50^{\circ}$ brix using $25 \%$ fresh juice and potassium metabisulphite $(350 \mathrm{ppm})$ was added as preservative. After a storage period of 10 days, the squashes were diluted with chilled water at 1:3 ratios for preliminary sensory analysis. RTS beverages and blended beverages with purple grape and phalsa juice were prepared by heat preservation. Carbonated beverages were also prepared using chilled carbonated water. Grape RTS beverages were prepared using $10 \%$ and $15 \%$ strained juice and adjusting the brix to $15^{\circ}, 18^{\circ}$ and $20^{\circ}$ for preliminary evaluation. The beverages were boiled and filled into pre-sterilized $200 \mathrm{ml}$ glass bottles and crown corked. In the case of carbonated beverages, chilled base was prepared by using 10 and $15 \%$ clear juice and calculated quantity of sugar to get $15^{\circ}, 18^{\circ}$ and $20^{\circ}$ brix in the final product. The chilled base was further diluted with chilled carbonated water and bottled immediately. Clarified grape juice was blended with purple grape and phalsa juices separately at 2:1 and 1:1 ratios respectively to improve the colour and flavour of the final RTS beverages. These blended juices namely grapepurple grape and grape-phalsa were bottled as above to prepare plain (by heat preservation) and carbonated RTS beverages. Then, all the beverages were evaluated initially to optimize the juice content, ${ }^{\circ}$ brix and acidity for the preparation of beverages in bulk for storage studies.

\section{Storage studies}

RTS beverages were subjected to storage studies at room temperature for a period of 6 months by drawing samples at bimonthly intervals to evaluate changes in chemical and organoleptic parameters. The products were also evaluated for sensory qualities viz., colour, flavour, taste and overall acceptability by a panel of 10 judges using a 9-point Hedonic scale where, score 1 is for 'dislike extremely' and 9 for 'like extremely' [21]. Sensory scores were analysed statistically by ANOVA using SPSS 15.0 to evaluate the significance at $\mathrm{P}<0.05$.

\section{Results and Discussion}

Schematic representation of the preparation of blended sour grape RTS beverages is presented in Figure 1. Analytical data of racked juices from sour grapes and purple grape juice, fresh phalsa juices is presented in Table 1. Various combinations of sugar, citric acid and juice contents were tested for the preparation of plain RTS, blended RTS and carbonated beverages to optimize their quantities by sensory analysis. The optimum conditions for RTS beverages were 15\% juice and $15^{\circ}$ brix in case of plain RTS, $15 \%$ juice and $18^{\circ}$ brix for blended RTS with purple grape juice, $10 \%$ juice and $18^{\circ}$ brix for blended RTS with phalsa. For squash $45^{\circ}$ brix was the optimum level. The beverages were prepared according to the standardized recipes and kept for storage

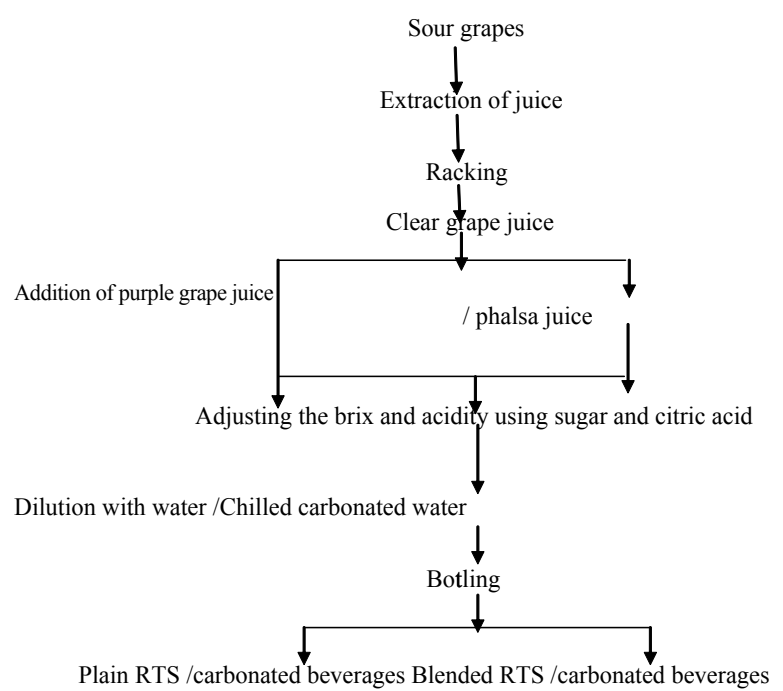

Figure 1: Flow chart for the preparation of blended sour grape RTS beverages.

\begin{tabular}{|l|l|l|l|}
\hline Parameter & Sour grape juice & Purple grape juice & Phalsa juice \\
\hline Colour & Greenish & Purple & Pink \\
\hline${ }^{\circ}$ Brix & $12.40 \pm 0.1$ & $13.2 \pm 0.1$ & $10.0 \pm 0$ \\
\hline Acidity, \% & $1.05 \pm 0.01$ & $1.20 \pm 0.05$ & $2.86 \pm 0.07$ \\
\hline $\mathrm{pH}$ & $3.16 \pm 0.02$ & $2.11 \pm 0.05$ & $2.79 \pm 0.12$ \\
\hline Reducing sugar, \% & $11.92 \pm 0.12$ & $9.66 \pm 0.16$ & $5.6 \pm 0.02$ \\
\hline Total sugars, \% & $12.15 \pm 0.05$ & $11.7 \pm 0.20$ & $6.0 \pm 0.04$ \\
\hline
\end{tabular}

Values are mean of triplicates \pm SD

Table 1: Physico-chemical analysis of racked fruit juice.

\begin{tabular}{|l|l|l|l|l|l|l|l|}
\hline \multirow{2}{*}{ Parameter } & \multicolumn{3}{|l|}{ Plain grape RTS } & \multicolumn{3}{l|}{$\begin{array}{l}\text { Grape-purple } \\
\text { grape blend }\end{array}$} & \multicolumn{2}{l|}{$\begin{array}{l}\text { Grape-phalsa } \\
\text { blend }\end{array}$} \\
\cline { 2 - 8 } & $\mathbf{1}$ & $\mathbf{2}$ & $\mathbf{1}$ & $\mathbf{2}$ & $\mathbf{1}$ & $\mathbf{2}$ \\
\hline${ }^{\circ}$ Brix & 15 & 15 & 18 & 18 & 18 & 20 \\
\hline Acidity, \% (as citric acid) & 0.14 & 0.15 & 0.2 & 0.2 & 0.19 & 0.21 \\
\hline Quantity of juice, \% & 15 & 15 & 15 & 15 & 10 & 10 \\
\hline $\begin{array}{l}\text { Proportion of blending } \\
\text { (Sour grape juice : purple } \\
\text { grape / phalsa fruit juices) }\end{array}$ & - & - & $2: 1$ & $2: 1$ & $1: 1$ & $1: 1$ \\
\hline
\end{tabular}

1 = plain, 2 = carbonated

Table 2: Optimized conditions for preparation of plain RTS, blended RTS beverages. 
Citation: Balaswamy K, Rao PP, Nagender A, Satyanarayana A (2011) Preparation of Sour Grape (Vitis Vinifera) Beverages and Evaluation of their Storage Stability. J Food Process Technol 2:116. doi:10.4172/2157-7110.1000116

Page 3 of 4

\begin{tabular}{|c|c|c|c|c|c|c|c|}
\hline \multirow{2}{*}{ Parameter } & \multirow{2}{*}{ Squash } & \multicolumn{2}{|c|}{ Plain grape RTS } & \multicolumn{2}{|c|}{ Grape-purple grape blend } & \multicolumn{2}{|c|}{ Grape-phalsa blend } \\
\hline & & 1 & 2 & 1 & 2 & 1 & 2 \\
\hline & \multicolumn{7}{|l|}{0 days } \\
\hline${ }^{\circ}$ Brix & $45.0 \pm 0.2$ & $15.0 \pm 0.1$ & $15.0 \pm 0.1$ & $18.0 \pm 0.10$ & $18.0 \pm 0.1$ & $18.0 \pm 0.11$ & $20.0 \pm 0.22$ \\
\hline Acidity, \% & $0.75 \pm 0.01$ & $0.14 \pm 0.02$ & $0.15 \pm 0.02$ & $0.22 \pm 0.04$ & $0.23 \pm 0.01$ & $0.19 \pm 0.01$ & $0.21 \pm 0.03$ \\
\hline $\mathrm{pH}$ & $2.45 \pm 0.01$ & $2.94 \pm 0.02$ & $3.02 \pm 0.01$ & $3.01 \pm 0.01$ & $3.13 \pm 0.01$ & $3.25 \pm 0.02$ & $3.17 \pm 0.02$ \\
\hline Reducing sugars, $\%$ & $42.1 \pm 0.25$ & $13.80 \pm 0.02$ & $13.90 \pm 0.36$ & $6.74 \pm 0.05$ & $5.85 \pm 0.01$ & $5.29 \pm 0.05$ & $6.82 \pm 0.04$ \\
\hline \multirow[t]{2}{*}{ Total Sugars, $\%$} & $44.8 \pm 0.25$ & $13.80 \pm 0.05$ & $13.46 \pm 0.11$ & $17.87 \pm 0.12$ & $17.80 \pm 0.04$ & $18.0 \pm 0.07$ & $19.1 \pm 0.06$ \\
\hline & \multicolumn{7}{|l|}{6 months } \\
\hline${ }^{\circ}$ Brix & $46.0 \pm 0.2$ & $15.0 \pm 0.1$ & $15.0 \pm 0.1$ & $18.0 \pm 0.05$ & $18.0 \pm 0.07$ & $18 \pm 0.05$ & $20.2 \pm 0.12$ \\
\hline Acidity, \% & $0.72 \pm 0.03$ & $0.14 \pm 0.01$ & $0.14 \pm 0.02$ & $0.20 \pm 0.01$ & $0.22 \pm 0.06$ & $0.18 \pm 0.10$ & $0.20 \pm 0.11$ \\
\hline $\mathrm{pH}$ & $2.35 \pm 0.02$ & $3.26 \pm 0.01$ & $3.16 \pm 0.01$ & $3.01 \pm 0.01$ & $3.12 \pm 0.03$ & $3.20 \pm 0.07$ & $3.11 \pm 0.02$ \\
\hline Reducing sugars, \% & $42.6 \pm 0.4$ & $14.31 \pm 0.07^{*}$ & $14.27 \pm 0.4^{*}$ & $9.74 \pm 0.05^{*}$ & $8.92 \pm 0.11^{*}$ & $8.29 \pm 0.02^{*}$ & $9.12 \pm 0.04 *$ \\
\hline Total Sugars, \% & $45.2 \pm 0.2$ & $14.76 \pm 0.24$ & $14.92 \pm 0.32$ & $17.87 \pm 0.12$ & $17.90 \pm 0.14$ & $18.0 \pm 0.12$ & $20.1 \pm 0.057$ \\
\hline
\end{tabular}

Values are mean of triplicates \pm SD

Table 3: Chemical analysis of squash and RTS beverages from sour grapes during storage.

\begin{tabular}{|c|c|c|c|c|c|c|c|}
\hline \multirow{2}{*}{ Storage period (Days) } & \multirow{2}{*}{ Squash } & \multicolumn{2}{|c|}{ Plain grape RTS } & \multicolumn{2}{|c|}{ Grape-purple grape blend } & \multicolumn{2}{|c|}{ Grape-phalsa blend } \\
\hline & & 1 & 2 & 1 & 2 & 1 & 2 \\
\hline 0 & $7.8 \pm 0.37$ & $7.5 \pm 0.24$ & $8.0 \pm 0.41$ & $8.0 \pm 0.33$ & $8.5 \pm 0.53$ & $8.5 \pm 0.53$ & $8.7 \pm 0.30$ \\
\hline 60 & $7.5 \pm 0.33$ & $7.1 \pm 0.16$ & $8.0 \pm 0.41$ & $7.5 \pm 0.33^{*}$ & $8.0 \pm 0.47^{*}$ & $8.0 \pm 0.37^{*}$ & $8.2 \pm 0.35^{*}$ \\
\hline 120 & $7.5 \pm 0.28$ & $7.0 \pm 0.16^{*}$ & $7.6 \pm 0.32^{*}$ & $6.8 \pm 0.42^{*}$ & $7.5 \pm 0.41^{*}$ & $7.5 \pm 0.58^{*}$ & $7.5 \pm 0.41^{*}$ \\
\hline 180 & $7.0 \pm 0.24^{*}$ & $6.8 \pm 0.26^{*}$ & $7.0 \pm 0.24^{*}$ & $6.5 \pm 0.58^{*}$ & $7.4 \pm 0.52^{*}$ & $7.5 \pm 0.55^{\star}$ & $7.5 \pm 0.41^{*}$ \\
\hline
\end{tabular}

( $\mathrm{n}=10$ panelists), $1=$ plain, $2=$ carbonated, * indicates significant difference compared to 0 days at $\mathrm{P} \leq 0.05$

Table 4: Overall sensory score of sour grape beverages.

studies. Similarly, carbonated RTS beverages were also prepared using $15 \%$ juice and $15^{\circ}$ brix in case of grape RTS, $15 \%$ juice and $18^{\circ}$ brix in case of purple grape and $10 \%$ juice and $20^{\circ}$ brix in case of phalsa (Table 2). Data on chemical analysis of beverages during 6 months storage period is given in Table 3. Squash prepared from sour grapes contained $45^{\circ}$ brix, $0.75 \%$ acidity and total sugars $44.8 \%$ and remained constant during the storage period. Plain RTS beverage showed $15^{\circ}$ brix, $0.15 \%$ acidity and $\mathrm{pH} 3.9$ and reducing sugars $13.96 \%$. No significant changes in parameters were observed during 2 and 4 months storage and hence the data was not presented in the table. However, changes in acidity, brix, $\mathrm{pH}$ were negligible and reducing sugars increased significantly $(\mathrm{P} \leq 0.05)$ after 6 months storage period in all RTS beverages. Similar observations were noticed in the study carried out on apple and apricot blended juices [22]. Sensory evaluation revealed that all the beverages tasted good initially and stored well during storage for 6 months (Table 4). Squashes were highly acceptable with characteristic grape flavour. A decrease in overall acceptability for RTS beverages prepared by grape juice alone is mainly due to absence of flavour or colour. Initial blending of grape juice with purple grape juice and phalsa juice improved appearance, colour and flavour characteristics and hence scored good. Similar studies on utilization of Bhokri grapes which were highly acidic, astringent with low sugar contents in the preparation of blended beverages with coloured and high brix juice of seedless grapes were reported earlier [23]. The sensory scores of blended juices were higher than the plain juices and further scores improved in carbonated beverages. The overall acceptability scores were differed significantly after 60 days storage in all the beverages.

In the present study, panelists preferred carbonated RTS beverages by giving higher scores when compared to non-carbonated beverages. Blended beverage with purple grape juice maintained its colour and flavour in both plain and carbonated beverages. The results are in agreement with the literature wherein carbonation of blueberry flavored milk beverages improved the sensory ratings of sweetness and blueberry flavor [24]. Visually, no colour changes were observed in carbonated beverages prepared from Roselle calyces (Hibiscus sabdariffa) during 3 months storage period at ambient temperature [25]. In the present study, minimal loss of visual color was found in blended beverages with phalsa, but scored well in terms of overall acceptability after 4 months storage period. It was observed the color deterioration (non-enzymatic browning) was at a faster rate in red grape juice concentrate during of 3 months storage at 10 to $30^{\circ} \mathrm{C}$ [26]. Similarly, losses in color was also observed in blueberry juice blends prepared with different proportions of apple juice, concord grape and venus grape juices and cranberry juice after storage of 3 months at $37^{\circ} \mathrm{C}$ [27].

\section{Conclusion}

The present study revealed that palatable and shelf stable beverages can be prepared from low valued sour grape juice by adjusting the juice quantity and sugar-acid ratio. Beverages blended with purple grape juice and phalsa juice yielded eye appealing products and received good scores throughout the storage period. Carbonation of blended beverages has an added advantage in improving the palatability during storage period. The study demonstrated that value added beverages from sour grapes could be prepared for commercial exploitation.

\section{Acknowledgement}

Authors thank Director, Central Food Technological Research Institute Mysore for providing facilities and permission to publish the data.

\section{References}

1. Prabhakara Rao PG, Balaswamy K, Velu V, Jyothirmayi T, Satyanarayana A (2009) Products from grapes of low soluble solids and their quality evaluation. Journal of Food Science and Technology 46: 77-79.

2. Iriti M, Faoro F (2009) Health-promoting effects of grape bioactive phytochemicals. Complementary and Alternative Therapies and the Aging Population. 445-474.

3. Adhikary SK, Harkare WP, Govindan KP, Chikkappaji KC, Saroja S, et al. (1987) De-acidification of fruit juices by electrodialysis II. Indian Journal of Technology 25: 24-27. 
Citation: Balaswamy K, Rao PP, Nagender A, Satyanarayana A (2011) Preparation of Sour Grape (Vitis Vinifera) Beverages and Evaluation of their Storage Stability. J Food Process Technol 2:116. doi:10.4172/2157-7110.1000116

4. Panda P, Garg MK, Surjeet J, Grewal RB (2005) Osmo-air drying of grapes (Perlette) for raisin preparation. Beverage and Food World 32: 51-54.

5. El-Mansy, HA. Sharoba AM. Bahlol HELM. El-Desouky Al (2005) Rheological properties of mango and papaya nectar blends. Annals of Agricultural Sciences, Moshtohor 43(2): 665-686.

6. Param Pal S, Davneet K, Gulab P (2010) Studies on the preparation of low alcoholic naturally carbonated blended beverage from guava and lemon. Internet Journal of Food Safety 12: 165-180.

7. Fernando CAUM, Marilia LSF, Ricardo LC, Daniel CF (2004) Sensory acceptance of mixed nectar of papaya, passion fruit and acerola. Scientia Agricola, (Piracicaba, Braz.) 61: 604-608.

8. Food and Agricultural Organization. Principles and practices of small- and medium-scale fruit juice processing. Chapter 9, Juice and beverage blends, Agriculture and consumer protection,FAO Corporate Document Repository.

9. Ahmad M, Chaudry MA, Khan I (1987) Development of a process for preparing comminuted guava drink. Pakistan Journal of Scientific and Industrial Research 30: $636-638$

10. Jain N L, Borker DH (1970) Preservation and storage stability of ready-to-serve beverages from guava. Indian Food Packer 24: 29-33.

11. Sims CA, Eastridge JS, O'Keefe SF, Bates RP (1995) Stability of nonpasteurized, refrigerated muscadine grape juice. Journal of Food Science 60: 506-508.

12. Khurdiya DS (1988) Preparation of lime juice for carbonated drink. Journal of Food Science and Technology 25: 315-316.

13. Khurdiya DS (1989) Lime juice-based carbonated drinks. Indian Horticulture 36: $28-29$.

14. Flora LF (1979) Optimum quality parameters of muscadine grape juices, beverages, and blends. Journal of Food Quality 2: 219-229.

15. Jain SK, Khurdiya DS (2004) Vitamin C enrichment of fruit juice based readyto-serve beverages through blending of Indian gooseberry (Emblica officinalis Gaertn.) juice. Plant Foods for Human Nutrition 59(2): 63-66.
16. Almeida Callou KRD, Sadigov S, Lajolo FM, Genovese MI (2010) Isoflavones and antioxidant capacity of commercial soy-based beverages: Effect of storage. Journal of Agriculture and Food Chemistry 58: 4284-4291.

17. Sowjanya G, Rokhada AK, Madalageri MB, Swamy GSK, Patil CP (2009) Preparation and storage of carbonated ready to serve (RTS) pomegranate beverage. Beverage and Food World 36: 30-32.

18. Lakshmi K, Vasanth Kumar AK, Jaganmohan Rao L, Madhava Naidu M (2005) Quality evaluation of flavoured RTS beverage and beverage concentrate from tamarind pulp. Journal of Food Science and Technology 42: 411-415.

19. Gonzales ON, Alejo JV, Brillante J, Valdecanas M (1985) Process for preparing non-carbonated and carbonated coconut water. Cocomunity APCC/QS/03: 31 42.

20. Ranganna S (1986) Handbook of Analysis and Quality Control for Fruit and Vegetable Products. Tata McGraw-Hill Publishing Co. Ltd., New Delhi, India.

21. Amerine MA, Pongborn RM, Roessler EB (1965) Principles of sensory evaluation of food. Academic Press, New York.

22. Imtiaz H, Alam Z, Muhammad A (2011) Evaluation of apple and apricot blend juice preserved with sodium benzoate at refrigeration temperature. World Journal of Dairy \& Food Sciences 6(1): 79-85.

23. Murali Krishna M, Khurdiya DS, Raychaudhuri M (1969) Utilization of Bhokr grape. Indian Food Packer 23(4): 1-2.

24. Yau NJN, McDaniel MR, Bodyfelt FW (1989) Sensory evaluation of sweetened flavored carbonated milk beverages. Journal of Dairy Science 72: 367-377.

25. Saeed AR, Ahmed MO (1977) Storage stability of carbonated beverage from Roselle calyces (Hibiscus sabdariffa). Sudan Journal of Food Science and Technology 9: 78-81.

26. Buglione M, Lozano J (2002) Nonenzymatic browning and chemical changes during grape juice storage. Journal of Food Science 67(4): 1538-1543.

27. Main G, Faupel M, Morris J, Mcnew R (2001). Quality and stability of blueberry juice blended with apple, grape and cranberry juice. Journal of Food Quality 24 (2): 111-125 